\title{
Gambaran Kompetensi Mahasiswa Prodi PIK Angkatan 2018 Dalam MemberikanPelayanan Penerimaan Rawat Inap di Laboratorium STIKes Husada Borneo
}

\section{An Overview Of The Students Competence Of Pik Department Batch 2018 In ProvidingServices For Inpatient Registration In Stikes Husada Borneo Laboratory}

\author{
${ }^{1}$ Ermas Estiyana, ${ }^{2}$ Alis Lusiana Prayogi Putri \\ Program Studi D-III Perekam dan Informasi Kesehatan, STIKes Husada Borneo
}

\section{Article Info}

Article history:

Received July 21, 2020

Revised August 30, 2020

Accepted August 31, 2020

\section{Keywords:}

Competencies

Students

Inpatient

Laboratory

\begin{abstract}
A medical and health information recorder must have knowledges, skills, and behaviours which are the competencies of the profession. One of the medical recorder competencies is "registering for all the visits in health care facilities (registration for outpatient and inpatient)". This reasearch aims to investigate the overview of students competencies of PIK Department batch 2018 in providing services for inpatient registration in STIKes Husada Borneo Laboratory. This research used descriptive qualitative method and was conducted on 56 students of STIKes Husada Borneo batch 2018. The sampling technique in this research was proporsiv sampling. Based on the results of the research, by using questionnaires and checklists, shows that the students' knowledge of the competence and procedures for inpatient registration are; 3,5\% good, 35,7\% enough, and 60,7\% less good, then the students' attitude toward patients are good (98.2\%) and less good $(1.78 \%)$, and the students' skills in inpatient registration are competent for $67.8 \%$ and not competent yet for $32.1 \%$. So it can be concluded that the students' competencies of PIK Department batch 2018 in providing services for inpatient registration in terms of knowledges, behaviours, and skills are not competent yet.
\end{abstract}

This is an open access article under the CC BY-SAlicense.

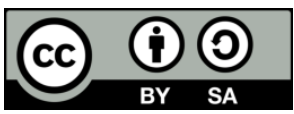

Corresponding Author:

Ermas Estiyana,

Program Studi D-III Perekam dan Informasi Kesehatan,

STIKes Husada Borneo,

Jl.A.Yani KM.30,5 No.4, Guntungmanggis, Kec.Landasan Ulin, Kota Banjar Baru, Kalimantan Selatan 70712

Email: ermas.abay06@gmail.com

\section{PENDAHULUAN}

Perekam Medis dalam memberikan pelayanan harus sesuai dengan kompetensi, berdasarkan pendidikan dan pelatihan serta berkewajiban mematuhi Standar Profesi Perekam Medis. Dari hal tersebut, perguruan tinggi negeri maupun swasta yang menyelenggarakan Progam Studi D-III Rekam Medis dan Informasi Kesehatan di Indonesia mampu untuk menghasilkan mahasiswanya menjadi lulusan yang memiliki 
kompetensi dengan standar profesi menurut Keputusan Menteri Kesehatan No. 377 tahun 2007. Standar profesi rekam medis dan informasi kesehatan disusun sebagai pedoman atau acuan bagi tenaga profesi manajemen informasi kesehatan dalam meningkatkan kualitas sumber daya manusia dalam menjalankan tugas profesinya sebagai perekam medis (1).

Seorang perekam medis dan informasi kesehatan harus mempunyai pengetahuan keterampilan dan perilaku yang merupakan kompetensi dari profesinya (2). Standar Profesi Perekam Medis, bahwa ada 2 kategori kompetensi yang harus dimiliki perekam medis dan informasi kesehatan. Kategori tersebut adalah kompetensi pokok dan kompetensi pendukung yang keduanya harus dimiliki oleh seorang perekam medis dan informasi kesehatan untuk menjalankan tugas di sarana pelayanan kesehatan (1).

Kompetensi pokok merupakan kompetensi mutlak yang harus dimiliki oleh profesi perekam medis, diantaranya Klasifikasi dan kodefikasi penyakit dan masalah-masalah yang berkaitan dengan kesehatan dan tindakan medis, Hukum dan Etika profesi, Manajemen rekam medis dan informasi kesehatan, Menjaga mutu rekam medis, Statistik kesehatan. Sedangkan kompetensi pendukung merupakan kemampuan yang harus dimiliki sebagai pengembang pengetahuan dan keterampilan dasar untuk mendukung tugas, yaitu Manajemen Unit Kerja manajemen informasi kesehatan dan Kemitraan Profesi. Artinya bahwa seorang profesi perekam medis harus menguasaikompetensi pokok yang telah ditetapkan oleh organisasi profesi untuk menjalankan kegiatan rekam medis dan informasi kesehatan, sedangkan Kompetensi pendukung merupakan kemampuan yang harus dimiliki sebagai pengembangan pengetahuan dan keterampilan dasar untuk mendukung tugas sebagai pengembangan dari kompetensi dasar (3).

Salah satu kompetensi perekam medis yang tercantum dalam Keputusan Menteri kesehatan RI No.377/MENKES/SK/III/2007 yaitu pada poin ketiga dengan kode unit kompetensi MIK.SR.03.001.01 yang berbunyi "meregistrasi atas semua kunjungan yang ada di fasilitas pelayanan kesehatan (registrasi pendaftaran pasien rawat jalan dan rawat inap)". Pentingnya penguasaan kompetensi ini untuk seorang profesional petugas rekam medis terkait dengan kualitas kerja dan jenjang karirnya di unit rekam medis, untuk menjalankan pekerjaan di rekam medis diperlukan sumber daya manusia yang memenuhi kompetensi perekam medis (4).

Berdasarkan uraian diatas penulis tertarik untuk melakukan penelitian gambaran kompetensi mahasiswa prodi PIK (Perekam dan Informasi Kesehatan) angkatan 2018 dalam memberikan pelayanan penerimaan rawat inap di laboratorium STIKes Husada Borneo tahun 2019?

\section{METODE PENELITIAN}

Jenis penelitian ini adalah penelitian deskriptif. Populasi pada penelitian ini adalah seluruh mahasiswa prodi Perekam dan Informasi Kesehatan (PIK) angkatan 2018 STIKes Husada Borneo sebanyak 125 orang. Sampel pada penelitian ini didapatkan menggunakan rumus slovin, sebanyak 56 orang. Variabel pada penelitian ini yaitu kompetensi yang dibagi menjadi 3 subvariabel yaitu pengetahuan, sikap dan keterampilan.

\section{HASIL DAN PEMBAHASAN}

\subsection{Hasil}

\section{A. Pengetahuan}

Dari hasil penelitian, distribusi frekuensi pengetahuan mahasiswa STIKes Husada Borneo tahun 2019 adalah sebagaimana pada tabel 1. 
Tabel 1. Distribusi Frekuensi Pengetahuan Mahasiswa Dalam Memberikan Pelayanan Penerimaan Rawat Inap Di L aboratorium STIKes Borneo

\begin{tabular}{llcc}
\hline No & Pengetahuan & Frekuensi & Persentase \% \\
\hline 1 & Baik & 2 & 3,5 \\
\hline 2 & Cukup & 20 & 35,7 \\
\hline 3 & Kurang & 34 & 60,7 \\
\hline & Total & $\mathbf{5 6}$ & $\mathbf{1 0 0}$ \\
\hline
\end{tabular}

Berdasarkan tabel diatas menunjukkan bahwa sebagian besar responden mempunyai pengetahuan yang kurang yaitu 34 responden $(60,7 \%)$. Dari hasil penelitian, distribusi frekuensi sikap mahasiswa STIKes Husada Borneo tahun 2019 adalah sebagaimana pada tabel 2.

Tabel 2. Distribusi Frekuensi Sikap Mahasiswa Dalam Memberikan Pelayanan Penerimaan Rawat Inap Di Laboratorium STIKes Husada Borneo

\begin{tabular}{cccc}
\hline No & Sikap & Frekuensi & Persentase \% \\
\hline 1 & Baik & 55 & 98,2 \\
\hline 2 & Kurang Baik & 1 & 1,78 \\
\hline & Total & $\mathbf{5 6}$ & $\mathbf{1 0 0}$ \\
\hline
\end{tabular}

Berdasarkan tabel diatas menujukkan bahwa sebagian besar responden bersikap baik kepada pasien dalam memberikan pelayanan penerimaan rawat inap di laboratorium STIKes Husada Borneo yaitu 55 responden $(98,2 \%)$.

\section{B. Keterampilan}

Dari hasil penelitian, distribusi frekuensi keterampilan mahasiswa STIKes Husada Borneo tahun 2019 adalah sebagaimana pada tabel 3.

Tabel 3. Distribusi Frekuensi Keterampilan Mahasiswa Dalam Memberikan Pelayanan Penerimaan Rawat Inap Di Laboratorium STIKes Husada Borneo

\begin{tabular}{cccc}
\hline No & Keretampilan & Frekuensi & Persentase $\%$ \\
\hline 1 & Berkompeten & 38 & 67,8 \\
\hline 2 & Belum Berkompeten & 18 & 32,2 \\
\hline & Total & $\mathbf{5 6}$ & $\mathbf{1 0 0}$ \\
\hline
\end{tabular}

Berdasarkan tabel diatas menunjukkan bahwa sebagian besar responden sudah berkompeten dalam memberikan pelayanan penerimaan rawat inap di laboratorium STIKes Husada Borneo yaitu 38 responden $(67,8 \%)$.

\section{Kompetensi}

Dari hasil penelitian, didapatkan kesimpulan dari ketiga subvariabel yaitu pengetahuan, sikap dan keterampilan, kompetensi mahasiswa prodi Perekam dan Informasi Kesehatan (PIK) angkatan 2018 dalam memberikan pelayanan penerimaan rawat inap di laboratorium STIKes Husada Borneo yang mencapai standar penilaian dari prodi D3 Perekam dan Informasi Kesehatan yaitu 70 pada tabel 4.

Tabel 4. Kompetensi Mahasiswa Dalam Memberikan Pelayanan Penerimaan Rawat Inap Di Laboratorium STIKes Husada Borneo

\begin{tabular}{cccc}
\hline No & Kompetensi & Frekuensi & Persentase $\%$ \\
\hline 1 & Berkompeten & 3 & 5 \\
\hline 2 & Belum Berkompeten & 53 & 95 \\
\hline & Total & $\mathbf{5 6}$ & $\mathbf{1 0 0}$ \\
\hline
\end{tabular}

Berdasarkan tabel diatas menunjukkan bahwa sebagian besar responden belum 
berkompeten dalam memberikan pelayanan penerimaan rawat inap di laboratorium STIKes Husada Borneo yaitu 53 responden (95\%).

\subsection{Pembahasan}

\section{A. Pengetahuan}

Dari hasil penelitian menunjukkan sebagian besar mahasiswa berpengetahuan kurang dikarenakan banyak mahasiswa yang menjawab salah pada soal nomor 12 "membuatkan surat persetujuan rawat inap jika diperlukan" sebanyak 54 orang (96\%). Dari hasil wawancara kepada mahasiswa setelah pengisian kuesioner pengetahuan tentang surat persetujuan rawat inap, mahasiswa mengaku telah mempelajari materi yang terdapat didalam kuesioner sebelumnya pada mata kuliah Manajemen Rekam Medis, maka seharusnya penelitian ini menunjukkan hasil yang baik. Akan tetapi, ternyata 96\% mahasiswa menjawab salah yang disebabkan beberapa faktor salah satunya adalah cara mahasiswa memahami suatu materi. Mahasiswa dapat mengerti dan mengingat lebih baik tentang suatu materi apabila mereka dapat memasukkan apa yang mereka pelajari kedalam suatu kerangka, dan mahasiswa tersebut termotivasi untuk belajar apabila kerangka tersebut cocok dengan apa yang dipahami mereka sebagai tujuan akhirnya, yaitu praktik klinis. Hal ini sejalan dengan Yunita (6), yang pernah melakukan penelitian tentang tingkat pengetahuan mahasiswa tentang tata laksana anak dengan gizi buruk, mahasiswa mengaku sudah pernah mendapat materi yang terdapat didalam kuesioner sebelumnya, karena tidak dipelajari kembali, mereka tidak dapat mengingat materi tersebut pada saat pengisian kuesioner.

\section{B. Sikap}

Dari hasil penelitian menunjukkan sikap mahasiswa terhadap pasien dalam penerimaan rawat inap sudah baik yaitu sebanyak 55 orang $(98,2 \%)$. Adapun faktor-faktor yang mempengaruhi sikap menurut Azwar (7), salah satunya yaitu pengaruh orang lain yang dianggap penting. Individu cenderung memiliki sikap yang konformis atau searah dengan sikap orang yang dianggap penting. Kecenderungan ini antara lain dimotivasi oleh keinginan untuk menghindari konflik dengan orang yang dianggap penting tersebut. Dalam hal ini pasien merupakan orang yang dianggap penting oleh petugas penerimaan pasien. Dengan bersikap ramah, sopan, tertib, penuh tanggung jawab dan berbicara dengan jelas seorang pasien mendapat kesan baik dari fasilitas pelayanan kesehatan.

Hal ini sejalan dengan penelitian Minardo (8) mahasiswa/petugas harus berperilaku sopan dan santun, menjaga tata krama mengikuti aturan yang berlaku di tempat praktik. Selain itu, mahasiswa juga telah mendapatkan teori serta praktik laboratorium mengenai cara berkomunikasi yang baik pada mata kuliah Komunikasi Efektif. Komunikasi dengan tampilan fisik dan mimik muka yang baik dan menyenangkan dapat memberikan isyarat penerimaan cara komunikasi oleh lawan bicara.

\section{Keterampilan}

Dari hasil penelitian menunjukkan keterampilan sebagian besar mahasiswa dalam praktek penerimaan pasien rawat inap adalah berkompeten yaitu sebanyak 38 orang $(67,8 \%)$. Adapun faktor-faktor yang dapat mempengaruhi keterampilan secara langsung salah satunya yaitu pengalaman. Pengalaman merupakan suatu hal yang akan memperkuat kemampuan seseorang dalam melakuman sebuah tindakan (keterampilan). Pengalaman membangun seseorang untuk bisa melakukan tindakan-tindakan selajutnya menjadi lebih baik yang dikarenakan sudah melakukan tindakan-tindakan dimasa lampaunya (9). Hal ini sejalan dengan Ranupantoyo dan Saud (10) mengatakan semakin lama seseorang bekerja pada suatu pekerjaan yang ditekuni pengalaman yang dijalani, maka akan semakin 
berpengalaman dan keterampilan kerja akan semakin baik. Berdasarkan hasil penelitian dapat diketahui bahwa keterampilan mahasiswa dalam praktik penerimaan rawat inap sebagian dari mahasiswa sudah berkompeten dikarenakan mahasiswa sudah ada pengalaman dalam praktek penerimaan rawat inap pada saat PKL 1 tahun 2018.

\section{Kompetensi}

Kompetensi mahasiswa angkatan 2018 dalam memberikan pelayanan penerimaan rawat inap di laboratorium STIKes Husada Borneo setelah penggabungan 3 subvariabel yaitu pengetahuan, sikap dan keterampilan dan yang telah mencapai standar penilaian dari prodi D3 Perekam dan Informasi Kesehatan yaitu 70 adalah sudah berkompeten 3 orang (5\%) orang dan belum berkompeten 53 orang (95\%). Hal ini menujukkan kompetensi sebagian besar mahasiswa dalam memberikan pelayanan penerimaan rawat inap adalah belum berkompeten.

\section{KESIMPULAN}

Berdasarkan hasil penelitian yang telah dilakukan pada mahasiswa mengenai Gambaran Kompetensi Mahasiswa dalam Memberikan Pelayanan Penerimaan Rawat Inap di Laboratorium STIKes Husada Borneo Tahun 2019 didapatkan kesimpulan sebagai berikut:

Kompetensi mahasiswa Prodi PIK angkatan 2018 dari segi pengetahuan sebagian besar masih kurang yaitu (60,7\%), dari segi sikap sebagian besar sudah baik yaitu $(98,2 \%)$, dan dari segi keterampilan sebagian besar sudah berkompeten yaitu $(67,8 \%)$. Kemudian dapat disimpulkan kompetensi mahasiswa Prodi PIK angkatan 2018 dilihat dari ketiga subvariabel sebagian besar belum berkompeten yaitu 53 orang (95\%).

\section{REFERENCES}

1. Menkes RI. (2007). Keputusan Menteri Kesehatan RI Nomor 377/MENKES/SK/III/2007 tentang Standar Profesi Perekam Medis dan Informasi Kesehatan.

2. Kholili, Ulil (2011). Pengenalan ilmu rekam medis pada masyarakat serta kewajiban tenaga kesehatan di rumah sakit. Jurnal Kesehatan Komunitas, Vol. 1: 66

3. Ritonga, Ega Fitriyani (2016). Tinjauan Kompetensi Petugas Rekam Medis Terhadap Mutu Pelayanan Kesehatan Di RSU Imelda Pekerja Indonesia. Medan: Akademi Perekam Medik dan Informasi Kesehatan (APIKES) Imelda Medan.

4. Budi, Savitri Citra (2011). Manajemen Unit Kerja Rekam Medis. Yogyakarta: Quantum Sinergis Media.

5. Wawan, A dan Dewi M. (2011). Teori dan Pengukuran Pengetahuan, Sikap, dan Perilaku Manusia. Yogyakarta: Nuha Medika.

6. Yunita, BE., Arundina,A., Armyanti,I., Liana, DF. (2015). Gambaran Tingkat Pengetahuan Mahasiswa Tentang Tatalaksana Anak dengn Gizi Buruk. Vol.1 No.1. 217.

7. Azwar, Saifuddin. (2013). Sikap Manusia: Teori dan Pengukurannya. Yogyakarta: Pustaka Pelajar. 
8. Minardo,J, Siyamti, D. Susilo,T (2018). Perilaku Santun Mahasiswa Perawat Dalam Kegiatan Belajar Praktik Keperawatan Di Rumah Sakit Umum Ambarawa. Vol.7 No.1., 32- 42.

8. Erpan, Erik. (2016). Gambaran Keterampilan Pemasangan Infus pada Perawat Vokasional dan Perawat Profesional RS PKU Muhammadiyah di Wilayah Yogyakarta. Karya Tulis Ilmian Proram Studi Ilmu Keperawatan, Universitas Muhammadiyah Yogyakarta.

9. Ranupandojo, H dan Saud, H. (2005). Manajemen Personalia. Edisi Ke-4 Penyunt. Yogyakarta: BPFE.

\section{BIOGRAPHIES OF AUTHORS}

Ermas Estiyana, Gelar Sarjana diperoleh dari STIKes Husada Borneo, Jurusan Bidan
Pendidik pada Tahun 2013. Magister Manajemen Kesehatan diperoleh dari STIE
Banjarmasin pada Tahun 2017. Saat ini aktif sebagai Ketua Program Studi dan
pengajar di Program Studi D-III Perekam dan Informasi Kesehatan STIKes Husada
Borneo.

